\title{
Bioluminescent System of Luminous Bacteria for Detection of Microbial Contamination
}

\author{
Maria A. Kirillova ${ }^{a}$, \\ Elena N. Esimbekova*a,b, Rajeev Ranjana, \\ Irina G. Torgashina ${ }^{a}$ and Valentina A. Kratasyuk ${ }^{a, b}$ \\ ${ }^{a}$ Siberian Federal University \\ 79 Svobodny, Krasnoyarsk, 660041, Russia \\ ${ }^{b}$ Institute of Biophysics SB RAS \\ FRC "Krasnoyarsk Science Center SB RAS" \\ 50/50 Akademgorodok, Krasnoyarsk, 660036, Russia
}

Received 04.02.2018, received in revised form 18.03.2018, accepted 16.05.2018

\begin{abstract}
Microbial contamination is usually analyzed using luciferin-luciferase system offireflies by the detection of adenosine-5'-triphosphate (ATP). There is an opportunity to assess the bacterial contamination of various objects based on a quantitative analysis of other nucleotides. In the present study, a bioluminescent enzyme system of luminous bacteria NADH:FMN-oxidoreductase (Red) and luciferase (BLuc) was investigated to understand if it can be used for quantitative measurements of bacterial cells by nicotinamide adenine dinucleotide (NADH) and flavin mononucleotide (FMN) detection. To increase the sensitivity of bioluminescent system to FMN and NADH, optimization of assay conditions was performed by varying enzymes and substrates concentrations. The lowest limits of detection were 1.2 nM FMN and 0.1 pM NADH. Escherichia coli cells were used as a model bacterial sample. FMN and NADH extraction was made by destructing cell membrane by ultrasonication. Cell suspension was added into the reaction mixture instead of FMN and NADH, and light intensity depended on number of bacterial cells in the reaction mixture. Centrifugation of sonicated sample as an additional step of sample preparation did not improve the sensitivity of method. The experimental results showed that Red and BLuc system could detect at least 800 thousand bacterial cells $m L^{-1}$ by determining concentration of NADH extracted from lysed cells, while 3.9 million cells $\mathrm{mL}^{-1}$ can be detected by determining concentration of FMN.
\end{abstract}

Keywords: NADH:FMN-oxidoreductase, bacterial luciferase, bacterial contamination, Escherichia coli.

Citation: Kirillova M.A., Esimbekova E.N., Ranjan R., Torgashina I.G., Kratasyuk V.A. Bioluminescent system of luminous bacteria for detection of microbial contamination. J. Sib. Fed. Univ. Biol., 2018, 11(2), 174-180. DOI: 10.17516/1997-13890060 .

(c) Siberian Federal University. All rights reserved

* Corresponding author E-mail address: esimbekova@yandex.ru 


\title{
Биолюминесцентная система светящихся бактерий для анализа микробного загрязнения
}

\author{
М.А. Кириллова ${ }^{a}$, Е.Н. Есимбекова ${ }^{a, \tilde{\sigma}}$, \\ Р. Ранджан ${ }^{\mathrm{a}}$, И.Г. Торгашина ${ }^{\mathrm{a}}$, В.А. Кратасюк ${ }^{\mathrm{a}, \tilde{\sigma}}$ \\ ${ }^{a}$ Сибирский федеральный университет \\ Россия, 660041, Красноярск, пр. Свободный, 79 \\ ${ }^{6}$ Институт биофизики СО РАН \\ ФИЦ «Красноярский научный центр СО РАН» \\ Россия, 660036, Красноярск, Академгородок, 50/50
}

Для анализа микробного загрязнения широко используется биолюминесиентный метод, основанный на определении аденозин-5'-трифосфата (АТР) с помощьью лющуиферинлюциферазной системы светляков. Сущуествует принципиальная возможность оценки степени бактериальной обсемененности различных объектов исходя из количественного анализа других нуклеотидов. В работе исследована возможность применения биолюминесиентной системы светящихся бактерий NADH:FMN-оксидоредуктаза (Red) и люцифераза (BLuc) для количественного анализа бактериальных клеток путем определения количества никотинамидадениндинуклеотида (NADH) и флавинмононуклеотида (FMN) в образце. Для увеличения чувствительности биолюминесцентной системы к FMN и NADH осуществлена оптимизация условий проведения анализа путем подбора концентраций ферментов и субстратов в реакционной смеси. Максимальная чувствительность биферментной системь Red + BLuc составила 1,2 нM FMN и 0,1 nM NADH. Для проведения количественного анализа бактериальных клеток использовали модельный бактериальный образеи-культуру Escherichia coli. Экстрагирование FMN и NADH проводили путем разрушения клеточной мембрань ультразвуковым дезинтегратором. Клеточную суспензию добавляли в реакционную смесь вместо раствора FMN или NADH, при этом интенсивность свечения биолюминесцентной системы зависела от количества бактериальных клеток в реакичонной смеси. Введение в пробоподготовку дополнительной процедуры цеентрифугирования образиа, подвергнутого ультразвуковой обработке, не привело кувеличению чувствительности метода. Таким образом, было показано, что чувствительности биферментной системь Red + BLuс достаточно для определения не менее 800 тыс бактериальных клеток в миллилитре путем экстрагирования NADH из разрушенных клеток. При анализе, основанном на определении концентрациии FMN в бактериальном образце, чувствительность метода составила 3,9 млн клеток на миллилитр.

Ключевые слова: NADH:FMN-оксидоредуктаза, бактериальная люцифераза, бактериальное загрязнение, Escherichia coli.

\section{Introduction}

Detection of microbial contamination in food (Bottari et al., 2015) and beverages is one of the most important aspects in food safety
(Frundzhyan et al., 2008). Maintenance of proper hygienic environment in hospitals (Zambrano et al., 2014), kitchens and manufacturing units (e.g. food vessels, containers, food processing units) 
(Shama and Malik, 2013) is also the prerequisite to maintain a healthy atmosphere. In this regard, conventional methods that are commonly applied are plate count assay (PCA) (Lahtinen et al., 2006), polymerase chain reaction (PCR) (Turgay et al., 2016), broth dilution method (Wiegand et al., 2008), selective agar plating, etc.

A traditional PCA and related methods involve incubation of a sample in culture media for over two days to get meaningful results. Moreover, these routine microbiological methods require trained personnel and are laborious, expensive and less sensitive. Therefore, adenosine triphosphate (ATP) bioluminescence method based on luciferin/luciferase reaction of fireflies has been widely used to monitor food hygiene and sanitary conditions. Indeed, ATP is an excellent marker for cell viability and microbial contamination since it is universally present in all living organisms. Noda and co-authors reported a detection of a single bacterial cell using mutant firefly luciferase (Noda et al., 2008).

Likewise, Mei et al. published a research paper which described how a bioluminescent enzyme system of luminous bacteria can be used for quantitative measurement of bacterial cells by means of nicotinamide adenine dinucleotide (NADH) detection (Mei et al., 2009). Similarly, flavinmononucleotide(FMN)can possibly emerge as a potential marker of microbial contamination since FMN and NADH are coenzymes which regulate a plenty of metabolic pathways in bacterial cells, and are also the substrates for a coupled enzyme system of luminous bacteria i.e. NADH:FMN-oxidoreductase (Red) and bacterial luciferase (BLuc) (Esimbekova et al., 2014). In current research, we studied the assay sensitivity of the coupled enzyme system of luminous bacteria Red + BLuc towards its substrates viz. FMN and NADH to implement it for the detection of microbial contamination using a standard bacterial strain.

\section{Materials and methods}

Materials

Lyophilized bacterial luciferase (BLuc: EC 1.14.14.3) from Photobacterium leiognathi (recombinant strain of Escherichia coli) and NAD(P)H:FMN-oxidoreductase (Red: EC 1.6.99.3) from Vibrio fischeri were produced at the Institute of Biophysics SB RAS, Krasnoyarsk. NADH and FMN were the products of Serva, Germany while tetradecanal was procured from Merck, Germany. Escherichia coli (E. coli) cells (BL21 codon Plus (DE3) RIPL) were used as a standard bacterial strain for real sample analysis. Bacterial cell lysis was carried out by an ultrasonicator (UZDN-2T, Russia). Luminescence measurements were performed using a luminometer (Lumat LB 9507, Berthold Technologies, Germany).

\section{Methods}

A loopful of freshly cultured E. coli cells were taken from a slant and transferred to $50 \mathrm{~mL}$ sterile Luria Bertini (LB) broth in an Erlenmeyer flask and cultivated at $30^{\circ} \mathrm{C}$ under shaking condition for 18 hours in an incubator shaker (New Brunswick Excella E25, Eppendorf, Germany). The approximate number of $E$. coli cells in the culture broth was measured using a UV-Vis spectrophotometer UVIKON 943 (Kontron Instruments, Italy) at $600 \mathrm{~nm}$ (1 O.D. $=5.0 \times 10^{8}$ cells $\left.\mathrm{mL}^{-1}\right)$.

A vial of lyophilized bacterial luciferase containing $0.5 \mathrm{mg}$ of an active enzyme and a vial of lyophilized NADH:FMN-oxidoreductase $(0.15 \mathrm{U})$ were diluted in $50 \mathrm{mM}$ phosphate buffer ( $\mathrm{pH}$ 6.8) each to obtain concentration of $0.25 \mathrm{mg} \mathrm{mL}^{-1}$ and $0.15 \mathrm{U} \mathrm{mL}^{-1}$, respectively. The diluted enzyme solutions were stored on ice throughout the experiment.

A stock solution of tetradecanal was prepared by taking a small amount of $50 \%$ tetradecanal in a glass vial followed by mild heating in a water bath 
till it melted completely. Then, $25 \mu \mathrm{L}$ of liquid tetradecanal was dissolved in absolute ethanol to obtain a concentration $0.25 \%$ and a final volume of $5 \mathrm{~mL}$. The working solution was prepared by dissolving $50 \mu \mathrm{L}$ of $0.25 \%$ tetradecanal solution in $5 \mathrm{~mL}$ of phosphate buffer ( $\mathrm{pH}$ 6.8) to obtain the concentration of $0.0025 \%$.

Stock solutions of $0.5 \mathrm{mM} \mathrm{FMN}$ and $0.5 \mathrm{mM}$ NADH were prepared using distilled water and phosphate buffer (50 mM, pH 6.8) respectively. The working standards were prepared by further dilution of the stock solutions.

Luminescence measurements were performed using the coupled enzyme system Red + BLuc in the presence of standard FMN $(1 \mathrm{nM}-10 \mu \mathrm{M})$ or NADH $(0.1 \mathrm{pM}-10 \mathrm{nM})$. The calibration curve for standard NADH was obtained by dispensing the reactants into a tube of luminometer in the following sequence: $300 \mu \mathrm{L}$, phosphate buffer (50 mM, pH 6.8); $40 \mu \mathrm{L}$, BLuc; $10 \mu \mathrm{L}$, Red; $20 \mu \mathrm{L}, 0.0025 \%$ tetradecanal and $10 \mu \mathrm{L}, 0.1 \mathrm{mM}$ FMN. The reaction mixture was evenly mixed in the tube and the luminescence baseline was recorded using a luminometer. Once the baseline was stabilized (approx. 6 minutes), $100 \mu \mathrm{L}$ of standard NADH solutions were injected to plot a calibration curve. The maximum luminescence intensity $\left(I_{\max }\right)$ was noted in terms of relative luminescence units (RLU).

Similarly, a standard curve for FMN was plotted. The reaction mixture contained $300 \mu \mathrm{L}$, phosphate buffer (50 mM, pH 6.8); $5 \mu \mathrm{L}$, BLuc and Red; $50 \mu \mathrm{L}, 0.0025 \%$ tetradecanal; $50 \mu \mathrm{L}$, $0.25 \mathrm{mM}$ NADH. The reaction was initiated by injecting $10 \mu \mathrm{L}$ FMN $(1 \mathrm{nM}-10 \mu \mathrm{M})$ in the tube, mixed evenly to measure the luminescence and plot the standard FMN curve.

Sample preparation for E. coli cells was carried out by using a) intact cells, b) sonicated cellular extract, and c) the clear supernatant of lysed $E$. coli cells. The samples were added to the reaction mixture instead of FMN or NADH. The baseline signal was measured every time before the sample was injected.

For the bacterial cell lysis, $1 \mathrm{~mL}$ of freshly cultivated E. coli cells (O.D.: $5.0 \times 10^{8}$ cells $\mathrm{mL}^{-1}$ ) was suspended in a microfuge vial and sonicated at $44 \mathrm{kHz}$ for 50 seconds with pauses for cooling after every $10 \mathrm{~s}$. Further, $10 \mu \mathrm{L}$ of bacterial extract were added to the previously defined reaction mixture instead of FMN or NADH to determine their concentration by measuring luminescence intensity. The same assay procedure was applied to live intact $E$. coli cells and the clear supernatant which was obtained by centrifuging the sonicated vials at $5000 \mathrm{rpm}$ for $10 \mathrm{~min}$ at $25^{\circ} \mathrm{C}$.

\section{Results and discussion}

Detection of FMN and NADH at low concentrations requires optimization of reactants. Therefore, the optimized values of the reactants were obtained by varying their concentrations to detect ultrasensitive levels of NADH in the sample. The concentrations of the reactants in the tube were $10 \mu \mathrm{g}$ BLuc, $0.002 \mathrm{U}$ Red, $1 \times 10^{-4} \%$ tetradecanal and $2 \mu \mathrm{M}$ FMN. Similarly, the optimal concentrations of the reactants in the assay mixture for FMN determination were $30 \mu \mathrm{M}$ NADH, $3 \times 10^{-4} \%$ tetradecanal, $0.63 \mu \mathrm{g}$ BLuc and $0.0002 \mathrm{U}$ Red (data not shown). The limit of detection (LOD) for FMN and NADH was calculated using the BLuc + Red system and was found to be $1.2 \mathrm{nM}$ FMN and 0.1 pM NADH.

During the assay, light emission was observed in the absence of NADH in the reaction mixture. That is the limiting factor of the detection system, and to minimize the signal, the reaction mixture was kept at room temperature for 6 minutes, after which NADH was added. The linear range for the NADH response curve was found to vary from $0.1 \mathrm{pM}$ to $1 \mathrm{nM}$ (Fig. 1a).

Previously, Jablonski and DeLuca had published the detection limit of 1 fM NADH 

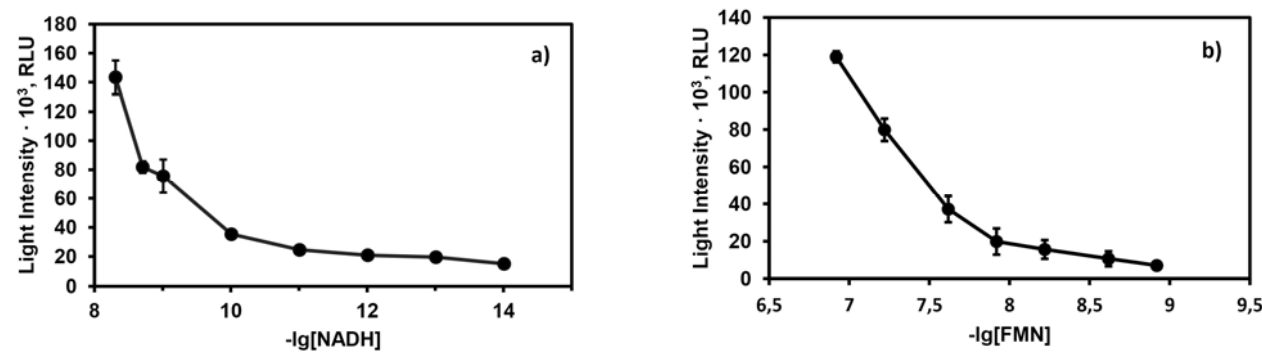

Fig. 1. The calibration curve for a) NADH and b) FMN
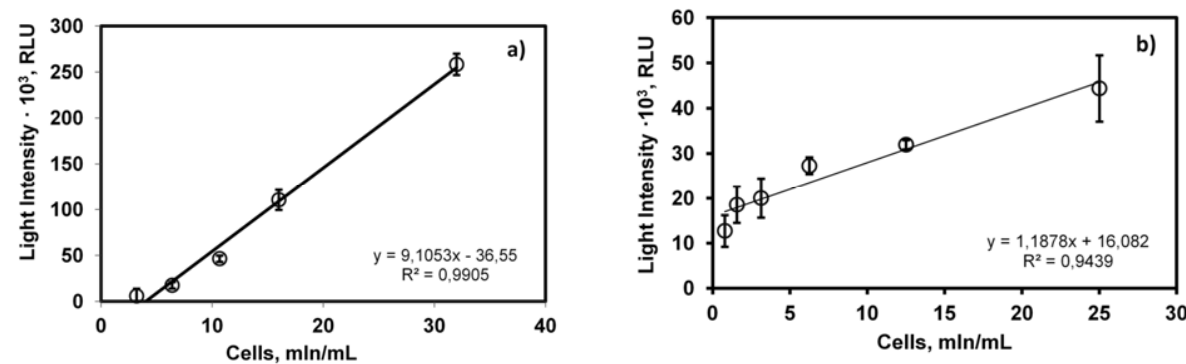

Fig. 2. Correlation between bioluminescence intensity and lysed cells number in the reaction mixture a) FMN determination; b) NADH determination

(Jablonski and DeLuca, 1979) while Mei et al. detected only $0.1 \mathrm{nM}$ NADH (Mei et al., 2009). The bioluminescent method of NADH detection is more sensitive than fluorescence spectrophotometry (Wang et al., 2009).

The standard curve for FMN is shown in Fig. 1b. Each point on the curve represents the mean value of four replicates for each measurement. The coupled enzyme system of luminous bacteria Red + BLuc was able to detect 1.2 nM FMN. The linear correlation between luminescence and FMN concentration was observed in the range from $1.2 \mathrm{nM}$ to $10 \mu \mathrm{M}$ of FMN.

After the intact E. coli cells were added to the assay mixture instead of FMN, the light intensity of the coupled enzyme system retained on the baseline level, which means the absence of FMN in the extracellular medium. Thus, it is impossible to use intact $E$. coli cells for a quantitative analysis. However, a different scenario was observed when intact $E$. coli cells were added to the reaction mixture instead of NADH. The increased luminescence output indicated the presence of NADH or other reductants in the medium. The correlation between bioluminescence intensity and the number of cells was observed after a sonicated cell suspension was added to the assay mixture (Fig. 2). The limit of detection was determined as the number of cells when light intensity of coupled enzyme system Red + BLuc was found to be three times higher than the baseline luminescence.

The sensitivity of the bioluminescent system was found to be 3.9 million cells $\mathrm{mL}^{-1}$ and 800 thousand cells $\mathrm{mL}^{-1}$ obtained through the detection of FMN and NADH, respectively. Centrifugation as an additional step of sample preparation did not improve the sensitivity of the method. The lowest limit of detection after centrifuged supernatant addition was about 5 million cells $\mathrm{mL}^{-1}$. The obtained results 
correlate with data published by Liu et al. who had achieved the level of $1.05 \times 10^{5}$ cells $\mathrm{mL}^{-1}$ by converting $\mathrm{NAD}^{+}$to NADH (Liu et al., 2014).

\section{Conclusion}

In this research we proved the possibility of coupled enzyme system of luminous bacteria Red + BLuc to be used for the detection of microbial contamination. We showed that the system Red + BLuc is able to detect at least 800 thousand bacterial cells $\mathrm{mL}^{-1}$. The analysis was based on determining NADH concentrations. The sample processing that was used in the study includes sonication and does not require centrifugation. So the Red + BLuc system can be used for detection of microbial cells in highly contaminated samples.

\section{Acknowledgements}

The research was partially supported by the Russian Foundation for Basic Research [project No. 16-34-60100], the state budget allocated to the fundamental research [project No. 0356-20170017] and Government of Krasnoyarsk Territory, Krasnoyarsk Region Science and Technology Support Fund to the research project and Russian Foundation for Basic Research [project No. 1644-242126].

\section{References}

Bottari B., Santarelli M., Neviani E. (2015) Determination of microbial load for different beverages and food stuff by assessment of intracellular ATP. Trends in Food Science \& Technology, 44: $36-48$

Esimbekova E., Kratasyuk V., Shimomura O. (2014) Application of enzyme bioluminescence in ecology. Advances in Biochemical Engineering / Biotechnology, 144: 67-109

Frundzhyan V.G., Parkhomenko I.M., Brovko L.Y., Ugarova N.N. (2008) Improved bioluminescent assay of somatic cell counts in raw milk. Journal of Dairy Research, 75(3): 279-283

Jablonski E., DeLuca M. (1979) Properties and uses of immobilized light-emitting enzyme systems from Beneckea harveyi. Clinical Chemistry, 25(9): 1622-1627

Lahtinen S.J., Gueimonde M., Ouwehand A.C., Reinikainen J.P., Salminen S.J. (2006) Comparison of four methods to enumerate probiotic bifidobacteria in a fermented food product. Food Microbiology, 23(6): 571-577

Liu H., Lin H., Mu Q., Lu X., Wang J., Khan M.N. (2014) Bioluminescence system assisted by $\mathrm{NAD}(\mathrm{P}) \mathrm{H}$ conversion to increase the sensitivity of quantitative bacterial cells assay. Innovative Food Science and Emerging Technologies, 26: 375-380

Mei C., Wang J., Lin H., Wang J. (2009) Quantitative detection of NADH by in vitro bacterial luciferase bioluminescent. Acta Microbiologica Sinica, 49(9): 1223-1228

Noda K., Matsuno T., Fujii H., Kogure T., Urata M., Asami Y., Kuroda A. (2008) Single bacterial cell detection using a mutant luciferase. Biotechnology Letters, 30: 1051-1054

Shama G., Malik D.J. (2013) The uses and abuses of rapid bioluminescence-based ATP assays. International Journal of Hygiene and Environmental Health, 216(2): 115-125

Turgay M., Schaeren W., Wechsler D., Bütikofer U., Graber H.U. (2016) Fast detection and quantification of four dairy propionic acid bacteria in milk samples using real-time quantitative polymerase chain reaction. International Dairy Journal, 61: 37-43

Wang J., Wang J., Lin H., Mei C. (2009) Rapid detection of total bacterial number using NADH fluorescence method. Microbiology, 36 (5): 773-779 
Wiegand I., Hilpert K., Hancock R.E.W. (2008) Agar and broth dilution methods to determine the minimal inhibitory concentration (MIC) of antimicrobial substances. Nature Protocols, 3: 163-175

Zambrano A.A., Jones A., Otero P., Ajenjo M.C., Labarca J.A. (2014) Assessment of hospital daily cleaning practices using ATP bioluminescence in a developing country. Brazilian Journal of Infectious Diseases, 18(6): 675-677 